\title{
The Development of Mathematics Teaching Material Based on Problem Solving to Support the Goal Achievement of Primary Education Mathematics Courses
}

\author{
Agus Susanta ${ }^{*}$ and Irwan Koto \\ Postgraduate of Primary School Teacher Education, University of Bengkulu \\ *Corresponding author. E-mail: agussusanta@unib.ac.id
}

\begin{abstract}
Mathematics teaching materials have an important role in supporting the achievement of the teaching goals of elementary school teacher education. One of the goals is to develop problem solving skills, but the existing teaching materials were not sufficient to facilitate problem solving. Therefore, problem solving based mathematics teaching materials were needed. The purpose of this research is to produce a mathematics teaching material model based on problem-solving, to support the goal achievement of mathematics primary education courses on the postgraduate program of primary school teacher education. This research and development used descriptive and evaluative methods. The descriptive method used to collect data on mathematics teaching materials, postgraduate student conditions, and supporting and inhibiting factors in developing the model of mathematics teaching material based on problem solving. The evaluative method was used to evaluate the testing process in developing mathematics teaching material model based on problem-solving. The product was developed through trials on postgraduate students from faculty of teacher training and education university of Bengkulu as the subjects. The data collection instruments were documents, questionnaires, and learning outcomes tests. Furthermore, the data were analyzed descriptively qualitatively. The results showed mathematics teaching material model based on problem-solving was valid and practice.
\end{abstract}

Keywords: Problem Solving, Mathematics, Teaching materials, Primary Education.

\section{INTRODUCTION}

Primary education mathematics course is a subject in the main competency group for postgraduate students of Basic Education FKIP UNIB. This course studies facts, concepts, principles, and procedures and solving primary school math problems, and learning strategies so that the students will be able to develop teaching materials based on the learning model used. Through this learning, the students are expected to have an understanding of mathematical skills about concepts and problem solving, mathematical pedagogy skills, and be able to develop the teaching materials and research.

The mathematics teaching materials used today are not sufficient to support the completion of the course. The main book used in lectures was the English mathematics textbook so that the students have difficulty understanding it. While, the supporting books in Indonesian are still compilations of several existing mathematics books. The books that are presented in English, the contents have not been much connected by the existing context in Indonesia, not much have been associated with something already familiar to the students. Meanwhile, supporting mathematics books in Indonesian, the presentation of mathematical material does not foster problem-solving skills, relationships with real life every day. The contents are more to pure mathematics, explaining the concept of defining properties, examples are then followed by exercise.

The impact is that student learning achievement is not optimal. If students are given a math assignment, they are not confident about their own work in the 
assignment and tend to imitate their friends' answers. It can be seen that the average score of the mathematics primary education course assignment is good but the average score of the exams is not good, both on the midterm and final semester exams.

Therefore, it is necessary to change the current mathematics teaching materials with problem solvingbased mathematics teaching materials. Because the basis of problem solving has concepts and principles that are thought to help students develop the ability to understand mathematical concepts, reason, solve problems, communicate mathematical ideas, and positive facts about mathematics.

Teaching materials are systematically made subject matter on which teachers and students use in the learning process [1]. The contents of the teaching material are create in such a way only to obtain specific goals from certain aspects of the student; and the systematic way of delivery is adjusted to the characteristics of the subjects and the characteristics of the students who use them [2]. Textbooks include main textbooks and supporting textbooks. The main textbook contains teaching materials for a field of study and is used as a main book for students and teachers. Complementary textbooks are books that are helpful or are in addition to the main textbook and are used by students and teachers. In addition, textbooks are a means to support the achievement of teaching goals. According to Badrul, textbooks are books that have a role in achieving teaching goals [3].

The mathematics textbook model used today contains activities to explain the meaning of a concept, sample problems and their solutions, and ends by giving problem exercises. Meanwhile, the students tend to follow the explanation from the author. Also, the mathematics material presented is less related to daily life or other sciences but contains more concepts and other symbols. Presentation of material does not foster exploration skills and problem solving ability. With the current textbook writing model, it is difficult for students to master problem-solving abilities as expected in the objectives of teaching mathematics.

Therefore, another model of mathematics teaching materials has been developed, which can overcome the weaknesses that exist in current mathematics teaching materials, to support the achievement of mathematics teaching objectives, as well as improve mathematics learning outcomes. These mathematics teaching materials are based on problem solving. So, it is suspected, problem solving-based mathematics teaching materials can overcome the weaknesses that exist in mathematics teaching materials today, especially to support the achievement of primary education mathematics teaching goals.
Problem solving is a process that applies previous knowledge, skills and understanding to new and unfamiliar situations. The process begins with the problem that has been created and ends with a resolution using the information provided. Problems do not have to be closed or have a single solution, but can be open or must be tried in various ways. For example, by collecting and analyzing data, the trial and error method. Wong Swee states that the ability to carry out problem management depends on five interrelated components, namely skills, concepts, processes, attitudes and metacognition [4].

The characteristics of the problem-solving approach is the teacher provides a fairly clear problem, and students clarify, interpret, and try to construct one or more solving processes. In the problem-solving approach, the teacher as a facilitator asks leading questions and exchanges ideas with students in the process of solving them, so that the teacher plays a role in assisting students to have a deep understanding of mathematical ideas and the process.

There are four stages in problem solving according to Polya in Billstein as follows: 1) understanding the problem, 2) devising a plan, 3) carring out the plan, and 4) looking back [5]. Problem solving emphasizes more on the process than just getting the answer. Polya in Susanta suggests strategies for problem solving including using diagrams, seeing patterns, making tables, working backwards, trying and matching, finding problems that have the same value, and simplifying problems [6]. Problem solving as a learning approach in J.A Vande Wale states that there are three problem solving ways related to mathematics learning: teaching for problem solving, teaching about problem solving, and teaching through problem solving [7]. Teaching for problem solving is teaching specific skills to develop skills that allowed the student to solve the problem. Teaching about problem solving is teaching students how to determine ways to solve problems, teaching through problem solving is the teaching method on which students learn mathematics through real situations, contexts, problems and modelling.

Problem solving as an approach to learning mathematics is the main focus applied in schools. In several countries such as America and Singapore, they have applied the problem as a focused approach to learning mathematics in schools. Problem solving is also a very strategic role in developing higher order thinking skills. By applying problem management, problems in learning mathematics for primary schools are very important.

Several previous studies on the development of teaching materials in schools [8];[9]. Teaching mathematics based on problem solving in postgraduate 
primary education has not been carried out. Berisha in problem solving research on mathematics textbooks for junior high schools in Kosovo [10]. The results show that: the results of the analysis, textbooks are less representative of the development of ability problems, this is because there are too many routine problem and non-contextual problems that are presented in the form of pure mathematics.

This study aims to produce a problem solving based mathematical teaching material model that can foster students' ability to understand mathematical concepts and develop problem solving skills.

\section{METHOD}

This type of research is research and development, using descriptive and evaluative methods. The descriptive method is used to: a) collect data on mathematics primary education teaching materials used today, b) the condition of students as learners who use teaching materials, and c) supporting and inhibiting factors for the development of the problem solvingbased mathematics teaching material model that will be produced. The evaluative method is used to evaluate the trial process based on the findings of the trial results.

The research subjects were all first semester students of the 2020/2021 academic year who took the primary education course in FKIP UNIB. The data collection techniques were collected by using questionnaires and observation techniques. Observations were done on students to observe the initial conditions of the books/teaching materials used, the quality of textbooks, and student learning outcomes. Teaching and learning process, which is seen from the activities of students, students in solving problems. Student response questionnaire and expert validation. Student response questionnaires to see potential and problems related to current teaching materials, the quality of teaching materials from the material aspects, presentation and readability, student responses to learning about mathematics learning. Expert validation questionnaire to test the validity of teaching materials.

In this study, an instrument will be developed which contains aspects: the potential and quality problems of problem solving-based mathematics teaching materials, mathematics learning outcomes. Aspects of presentation, and quality of readability aspects.

The instruments related to mathematics learning outcomes consist of two parts, namely: the ability to understand mathematical concepts and mathematical problems. Meanwhile, the instrument related to student responses to the problem-solving-based mathematics teaching material model is a questionnaire. The research procedures and stages in Sugiyono [11] are as follows: 1) describe the potential and problems related to teaching materials, 2) collect information on this initial study, 3) design of teaching materials, 4) validate the design of teaching materials, and 5) improving the design of teaching materials [11].

The data analysis used qualitative and quantitative analysis. The results of this analysis combined with problem solving theory are used to compile problem solving based mathematics teaching materials. The trial data of mathematics teaching materials from the material aspects, presentation aspects, and readability aspects were analyzed qualitatively and quantitatively. The results of logical validation analysis by experts are estimated using the Aiken validity index with the criteria $\geq 0.50$, using the Aiken formula:

$$
V=\sum_{n=1}^{N} \frac{i n_{i}}{[N(c-1)]}
$$

Information:

$$
\begin{aligned}
i n_{i}= & \text { the assessor's score for each aspect minus } \\
& \text { the lowest assessment category } \\
c \quad= & \text { highest category } \\
N \quad= & \text { total of validator [12] }
\end{aligned}
$$

While the instrument related to student responses to the problem solving model of mathematics teaching materials in the form of a questionnaire, using actual conversion into a scale of five was adapted from [13] as shown in the Table. 1.

Table 1. Actual Score Conversion to Five Scale Value

\begin{tabular}{|c|c|}
\hline Interval Score & Category \\
\hline$X>\bar{X}_{l}+1,8 s b_{i}$ & Very Good \\
\hline $\bar{X}_{l}+0,6 s b_{i}<X \leq \bar{X}_{l}+1,8 s b_{i}$ & Good \\
\hline $\bar{X}_{l}-0,6 s b_{i}<X \leq \bar{X}_{l}+0,6 s b_{i}$ & Sufficient \\
\hline $\bar{X}_{l}-1,8 s b_{i}<X \leq \bar{X}_{l}-0,6 s b_{i}$ & Bad \\
\hline$X \leq \bar{X}_{l}-1,8 s b_{i}$ & Very Bad \\
\hline
\end{tabular}

Information:

$X \quad=$ Empirical Score

$\bar{X}_{l} \quad=$ Average ideal

$\bar{X}_{l}=\frac{1}{2}$ (Maximum ideal score + Minimum ideal score $)$

$s b_{i}=$ Ideal standard deviation

$s b_{i}=\frac{1}{6}$ (Maximum ideal score + Minimum ideal score $)$

Maximum ideal score $=\sum$ Item Criteria $\mathrm{x}$ Highest score Minimum ideal score $=\sum$ Item Criteria $\mathrm{x}$ lowest score

\section{RESULTS AND DISCUSSION}

At the initial stage, it was found that the textbook of teaching materials used in basic mathematics education courses contained explanations of concepts, definitions, examples and exercise problems. The existing teaching materials do not yet support problem-solving skills and contextual approaches. Concepts of mathematical 
procedures can be taught through problem solving. The problem solving that has been done so far has not fully referred to the problem-solving process but is still more of a mathematical application to solve algorithmic problems by applying the formulas that have been taught, not including the problem-solving stages that lead to problem-solving abilities. Therefore, the development of problem solving-based mathematics teaching materials was chosen.

Mathematics teaching materials designed based on problems solving. A problem is something that needs solving. For someone to be able to solve a problem, that person must have the ability to solve problems. Problem solving is developed in the basic Polya stages, namely understanding the problem, planning a plan, carrying out the plan, and looking back. Mathematical teaching materials based on problem solving that developed are then subjected to validation and limited trials for improvement.

Teaching materials based on problem solving were validated by three experts. The purpose of validation is to find out the weaknesses and lack of teaching materials, as well as to obtain input, suggestions for improvement of teaching materials before being tested. The validator also assesses the feasibility of teaching materials. The validation results of teaching materials are shown in the following table. 2 .

Tabel. 2. The results of the validity test used the Aiken validity index

\begin{tabular}{|c|c|c|}
\hline Grading aspect & Aiken index & category \\
\hline Content & 0,944 & Valid \\
\hline Presentation & 0,933 & Valid \\
\hline Readability & 0,967 & Valid \\
\hline
\end{tabular}

Based on Table 1, the three aspects, namely content, percentage, and readability are scored in the valid category. Although the valid category of teaching materials has several entries to add more contextual problems, the use of images is adjusted to the context of the problem so that it is clearer. Based on the suggestions and enter the corrected teaching material validator. Furthermore, the teaching materials were tried out on limited subjects in postgraduate students who took the primary education course in the academic year 2020/2021.

Limited trials on a small scale of the developed teaching materials were tried out on 30 students who took mathematics primary education courses to see the practicality of the teaching materials developed. After testing the teaching materials, subjects were given a questionnaire to see student responses to the use of teaching materials which has been developed. Following are the results of student responses to problem solving based teaching materials seen from the aspects of appearance, presentation and benefits can be seen in Table 3.

Table 3. Result of student responses to the use of teaching materials which has been developed

\begin{tabular}{|l|c|l|l|}
\hline Aspect & Average score & Interval & Category \\
\hline Appearance & 22 & $6-24$ & Very practical \\
\hline Presentation & 31,5 & $9-36$ & Very practical \\
\hline Benefits & 11,86 & $3-12$ & Very practical \\
\hline
\end{tabular}

Table 3 shows that the three aspects of appearance, presentation and benefits are in very practical criteria. Several suggestions for improvements to be used as improvements to this teaching material include an explanation for each image that needs to be added. Meanwhile, the percentage of each aspect of the practicality trial can be seen in Figure 1 below.

Figure 1 shows that the appearance aspect has of the highest percentage which is strongly agreed $70,95 \%$, followed by the benefit aspect of $54.44 \%$, then the presentation aspect at $51.85 \%$. Thus the teaching materials developed are suitable to use in learning.

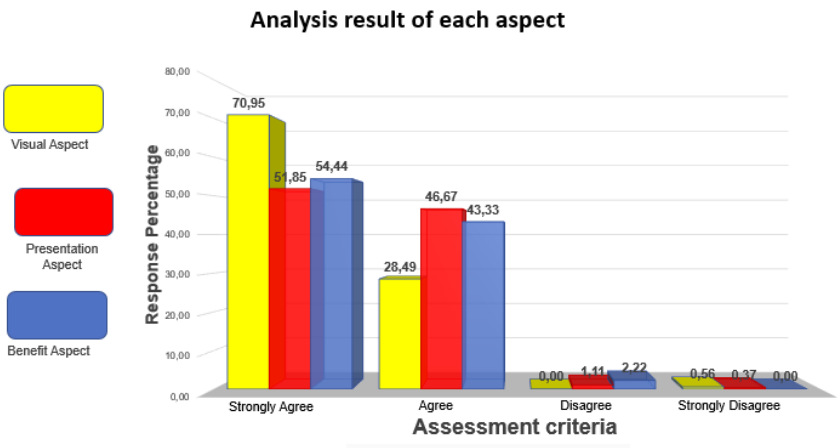

Figure 1. The percentage of student responses for each aspect from the trial of teaching material

During the learning process, using problem solving based teaching materials, this helps students to be more active in understanding the concept of learning independently and solving the problems given. In its application, lecturers act more as guides and directors by providing opportunities for active student participants to find their own solutions so that they are expected to last long in their memories. Problemsolving based learning requires learners to be more active and independent in building concepts and principles under the supervision of educators.

The ability to solve problems in mathematics is important for postgraduate students as a primary teacher so that they have sufficient skills to guide their students in learning mathematics, solving problems, learning mathematics in various problem solving contexts. Students who take classes with a problem solving approach have a wider opportunity to learn mathematical processes related to communication, representation, modelling and reasoning. The selection of the problem becomes an obstacle because it might be 
a problem for one student but it might not be a problem for other students because of the diversity of students. Through this teaching material, it will be able to develop new knowledge through problem solving and create new ideas.

\section{CONCLUSIONS AND SUGGESTIONS}

Based on the results and discussion, therefore it can be concluded that the problem solving-based primary education mathematics teaching materials developed received a good response. Therefore, that the problem solving-based mathematics teaching materials that have been developed are suitable for use in learning.

As suggestion, in the preparation of teaching materials, must be given challenging problems that involve many solutions, many answers are not just routine questions in the form of practice questions but are more developed on non-routine questions, open questions, non-traditional questions, and application questions. Contextual problems are presented in different representations.

\section{REFERENCES}

[1] Panen, P. College Teaching, four-part book "Development of Teaching Materials. Jakarta : PAU-PPAI, Open University, 1996.

[2] Belawati, T. Book assessment System. Bookkeeping Center. Jakarta: Open University, 2003.

[3] Badrul, Hayat. Book Assessment system. Bookeeping Center. Jakarta, 2001.

[4] Wong Swee. Effects of Heuristics Intruction on Pupils' Mathematical, Problem-Solving Process EARCOME 2002 Proceeding Vol. 2.Singapore: Welon Printing Co Pte Ltd, 2002.
[5] Billstein. A Problem Solving Approach to Mathematics for Elementary School Teachers. NY: Addison-Esley Publishing Company, 1993.

[6] Susanta, A. Professional Learning for Teaching Mathematics Through Problem Solving in Indonesian Primary Schools. Thesis of Doctor of Philosophy of Curtin University, 2012.

[7] J.A Vande Wale. Elementaray School Mathematics Teaching Developmentally. Virginia Commonwealth University, 1990

[8] Sengul, Skatranci, Y. Free Problem Posing cases of Prospective Mathematics Teachers: Dificulties and Solutions. Prceia-Social and Behavioral Sciences 174(2015) 1983-1990), 2014.

[9] Ariskasari, D.\& Pratiwi D.D. The development of Mathematical module based problem solving on vector material. Journal of Mathematics, Desimal 2(3),2019, 249-258.

[10] Berisha, V., Thaqi, X., \& Jashari, H. Problem solving in mathematics textbooks for lower secondary school in kosovo. ICRAE Coference Procedding ISSN: 2308-0825, 2014.

[11] Sugiyono. Educational Research Methods. Bandung: Alfabeta,2006.

[12] Aiken, L.R. Content validity and reliability of single items or questionnaires. Educational and psychological measurenment, 40(4) 955-959, 1980.

[13] Widoyoko, E.P. Evaluation of the Learning Program. Yogyakarta: Pustaka Pelajar, 2013. 